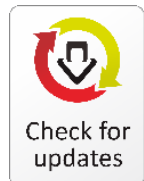

updates

Article Type: Research Paper

\title{
Transfer Pricing, Agency Costs, and Financial Reporting Aggressiveness: An Empirical Study in Indonesia
}

\author{
Eva Herianti ${ }^{1}$ and Amor Marundha ${ }^{2}$
}

\section{마에}

\section{AFFILIATION:}

${ }^{1}$ Department of Accounting, Universitas Muhammadiyah Jakarta, Indonesia.

${ }^{21}$ Department of Accounting, Universitas Bhayangkara Jakarta Raya, Jakarta, Indonesia

\section{*CORRESPONDENCE:}

heriantieva@gmail.com

THIS ARTICLE IS AVALILABLE IN:

http://journal.umy.ac.id/index.php/ai

DOI: 10.18196/jai.2003132

\section{CITATION:}

Herianti, E., \& Marundha, A. (2019). Transfer Pricing, Agency Cost, and Financial Report Aggressiveness: An Empirical Study in Indonesia. Journal of Accounting and Investment, 20(3), 325-338.

\section{ARTICLE HISTORY}

Received:

23 March 2019

\section{Reviewed:}

4 August 2019

Revised:

12 August 2019

Accepted:

29 August 2019

\begin{abstract}
The purpose of this study is to explore the effect of transfer pricing strategy and agency cost on financial reporting aggressiveness. This paper used 61 manufacturing industries listed on the Indonesia Stock Exchange from 2013 to 2017 period among which 305 companies were selected by purposive sampling method to be studied. The research questions were tested using panel data regression analysis. This study found that transfer pricing strategy had no significant effect on financial reporting aggressiveness but agency cost had negative and significant effect on financial reporting aggressiveness. Furthermore, control variables as growth and return on asset had positive and significant effect on financial reporting aggressiveness while size had negative and significant effect on financial reporting aggressiveness. Results of this study indicated that managers did not use transfer pricing strategy in managing earnings because there was regulation of OECD to control manager behaviour in implementing transfer pricing strategy. In addition, agency cost was one of the important factors in reducing manager behaviour to meet their interests.
\end{abstract}

Keywords: Transfer Pricing; Agency Cost; Financial Reporting Aggressiveness.

\section{Introduction}

Aggressiveness of financial reporting is earnings management action taken by managers within or beyond the limits of applicable accounting principles (Frank, Lynch, \& Rego, 2009). Watts and Zimmerman (1990) explained that one of the motivations for managers to aggressively engage in financial reporting is to obtain bonus/incentives, debt contracts, or political cost. Therefore, managers need to convince shareholders that their performance has been met through optimization of accounting profit figures. This condition results in managers trying to manage profits opportunistically to meet their interests.

Several cases of financial reporting aggressiveness that occur in global companies prove that managers manage earnings to meet their interests, such as the case of Toshiba that occurred in 2015 (Sofyani \& Rahma, 2017). In addition to the Toshiba case, several cases of financial reporting aggressiveness have occurred globally, namely the Enron, Worldcom, Tyco, Health South, and Xerox cases (Ujiyantho \& Pamungkas, 2007). 


\section{Herianti \& Marundha \\ Transfer Pricing, Agency Costs, and Financial Reporting Aggressiveness...}

Cases of financial reporting aggressiveness do not only occurr in global companies, but also in Indonesian companies, such as the cases of PT. Kimia Farma, Tbk; PT. Indofarma, Tbk; PT. Lippo, Tbk; PT. Katarina Utana, Tbk; PT. Bumi Resources, Tbk; and PT. Ades Affindo, Tbk (Vajriyanti, Widanaputra, \& Putri, 2015). These cases prove that the aggressiveness of financial reporting is still managers' strategy in managing profits opportunistically to meet their interests.

The aggressiveness of financial reporting action can be done through transfer pricing policies to manage earnings. In this case, the transfer pricing scheme carried out by managers is to set accounting profit figures as the managers wishes. The aim is to achieve the accounting profit target, so as to provide a positive signal to shareholders regarding the company's prospects. Scott (2015) stated that the manager's opportunistic policy to manage earnings is motivated by the amount of tax that is borne by the company, so that the tax burden owed becomes smaller as accounting profits have been set by the manager.

Santosa and Suzan (2017) explained that transfer pricing is the price contained in each product or service from one division to another in the same company or between companies that have a special relationship. Transfer pricing is carried out by managers to manipulate accounting profit figures through transactions with parties that have a special relationship either through transactions with business groups that obtain tax holiday facilities, transfer profits to business groups that have suffered losses, as well as making transactions to business groups in tax-exempt countries or low tax rates.

The Director of International Taxation in Indonesia stated that several companies in one business group in Indonesia tended to adopt a transfer pricing policy to multiply profits from one company to another that had smaller tax obligations. The method used in Indonesia for transfer pricing policies is, (1) transfer pricing transactions are carried out when there is one company in a business group that receives tax holiday facilities. This is done because companies that get tax holiday facilities do not have tax obligations, and (2) transfers a portion of profits to companies in a business group that records net losses. This condition is done because the company that loses has no tax obligations.

The results of research conducted by Hwang, Chiou, \& Wang (2013) shows that most transactions with related parties are arranged to meet the interests of managers. Beuselink and Deloof (2014) stated that business groups are more likely to be involved in aggressiveness of financial reporting than non-business groups. Rasheed, Abdul, \& Mallikarjunappa (2018) and Marchini (2018) stated that the higher transfer pricing policy undertaken by related parties shows the higher aggressiveness of corporate financial reporting. Meanwhile, Ying and Wang (2013) showed that companies do aggressiveness in financial reporting followed by excessive tunneling to control shareholders in removing profits imported from companies that conduct IPOs.

Aharony, Wang, and Yuan (2010) stated that many companies use related party transactions to improve company performance during the initial public offering (IPO) period. His findings prove that sales transactions with related parties are mostly used by 


\section{Herianti \& Marundha \\ Transfer Pricing, Agency Costs, and Financial Reporting Aggressiveness...}

companies that conduct IPOs with the parent company to enable companies to regulate accounting profit figures, so they can affect the market, although this transaction can benefit the company.

The transfer pricing policy that occurred in Indonesia caused the Indonesian government to issue Regulation of the Minister of Finance (PMK) Number 213 / PMK.03 / 2016 regarding Additional Documents and / or Information that Must Be Stored by Taxpayers conducting Transactions with Parties with Special Relationships. This Regulation of the Minister of Finance (PMK) is an improvement to the Regulation of the Director General of Tax Number 23 / PJ / 2013 which regulates transfer pricing. This Regulation of the Minister of Finance (PMK) not only regulates the requirement for making additional transfer pricing documents for transactions with related parties that are abroad, but with related parties that are in the country. The purpose of the issuance of this regulation is to increase the transparency of the transfer pricing policy, so that this policy can minimize opportunistic managerial actions.

One of the factors that can influence the behavior of company management in reducing the aggressiveness of financial reporting is the existence of agency costs used by companies in monitoring management behavior to suit the interests of shareholders. Agency costs are costs incurred by the principal to the agent to act in accordance with the interests of the principal. The aim is to reduce conflicts of interest between principals and agents. Agency costs incurred by the company, namely, (1) audit fees to control opportunistic managerial actions, (2) bonding costs to ensure that agents will not make decisions that are detrimental to the principal, and (3) residual loss as a result of manager decisions that should be able to optimize shareholder profits. This condition affects managers to reduce opportunistic behavior in managing company profits.

Some previous research findings about the effect of transfer pricing and agency costs on financial reporting aggressiveness are the results of Rasheed et al. (2018), Marchini (2018), and Hwang et al. (2013) showed that transfer pricing has a positive and significant effect on management. In addition, the findings of Man, Locke, and Wellalage (2018) shows that agency costs negatively affect earnings management. The limited number of previous studies examining the effect of transfer pricing and agency costs on the aggressiveness of financial reporting shows that this research is important to be carried out by researchers. This is proven by the inconsistency of the findings of the previous research that has not been found.

The contribution of this study is to fill the void of literature studies that examine the effect of transfer pricing and agency costs on the aggressiveness of financial reporting. In addition, this research can be used by various stakeholders in decision making. The effectiveness of regulations governing transfer pricing can reduce the opportunistic behavior of managers, as well as the existence of agency costs in order to reduce the aggressiveness of financial reporting. Based on this description, this study aims to examine the effect of transfer pricing and agency costs on the aggressiveness of financial reporting on manufacturing companies listed on the Indonesia Stock Exchange (IDX) for the 2013-2017 period. 


\author{
Herianti \& Marundha \\ Transfer Pricing, Agency Costs, and Financial Reporting Aggressiveness...
}

\title{
Literature Review and Hypotheses Development
}

\section{Agency Theory}

The capital market is an alternative for shareholders to invest in companies. That is, shareholders entrust their resources to be managed by the company. The aim is to increase shareholder prosperity in the future (Jensen \& Meckling, 1976). However, the company or manager has their own motivation to fulfill their interests which causes a conflict of interest between shareholders and managers.

Conflicts of interest experience significant developments between shareholders and managers when the motivation of managers is to get bonuses in fulfilling their interests. Ali and Hirshleifer (2017) explain that the opportunism of company managers shows that managers have the motivation to achieve profit targets and hide information that is less favorable for shareholders or the information conveyed by managers to shareholders does not indicate the actual condition. As a result of the conflict of interest, the shareholders try to suppress the manager's opportunistic behavior through monitoring mechanisms or compensation schemes, so that managers can meet the interests of shareholders.

The impact of a conflict of interest is the emergence of agency costs. Agency costs are costs incurred to reduce conflicts of interest. Agency costs incurred by the company such as, (a) audit fees as a form of costs incurred to oversee the actions of company management to act in the interests of shareholders, (b) bonding costs as a form of guarantee that company management does not take profits based on the facilities obtained, and (c) costs to restore the company's reputation if the company's management does not manage the company well, giving rise to lawsuits.

Financial reporting aggressiveness Financial accounting standards are designed to provide opportunities for company management to choose various alternative accounting methods in the financial reporting process. The aim is to adjust reporting of transactions and economic events according to the substance of transactions and industry practices, so as to improve the reliability of accounting information published by company management. However, the alternative flexibility of this accounting method is then used by company management to act opportunistically in managing earnings aggressively, called the aggressiveness of financial reporting.

Frank et al. (2009) explain that the aggressiveness of financial reporting is earnings management actions taken by company management within or beyond the limits of applicable accounting principles. The aggressiveness of financial reporting is done intentionally by managers to meet the interests of managers. The aggressiveness of financial reporting is an implementation of company management decisions that are not in accordance with applicable standards (Schipper, 1999). The aggressiveness of financial reporting is carried out by company management because accounting standards are based on an accrual basis. That is, recognition of business transactions is based on the time the transaction occurred not when the cash is received. This allows 


\author{
Herianti \& Marundha \\ Transfer Pricing, Agency Costs, and Financial Reporting Aggressiveness...
}

company management to manage the company's revenue, so that it will affect accounting profit figures.

\title{
Transfer Pricing
}

Transfer pricing is a classic phenomenon that often occurs in the field of taxation especially those relating to transactions with related parties or have special relationships. Santosa and Suzan (2017) explained that transfer pricing is the price contained in each product or service from one division that is transferred to another division within the same company or between companies that have a special relationship. Meanwhile, Suandy (2006) explained that transfer pricing is an act of allocating corporate entity profits in one country to another country's corporate entity in a group of companies aiming at reducing the corporate tax burden.

The transfer pricing policy is carried out by companies that have special relationships or related parties. The purpose of transfer pricing is to manage the company's tax burden, so that corporate tax liabilities can be minimized. Lee, P, and Seo (2013) explained that there are two approaches in studying transfer pricing policies, namely, (1) the transaction efficiency hypothesis explains that related party transactions can be an efficient contracting tool under incomplete information conditions by reducing transaction costs (Williamson, 1975; Stein, 1997 ; Khana \& Palepu, 1997; Shin \& Park, 1999), and (2) the conflict of interest hypothesis explains that related party transactions become dangerous practices arising from moral hazard. The conflict of interest hypothesis explains that related party transactions are carried out in the interests of controlling shareholders to take over the wealth of minority shareholders (Jensen \& Meckling, 1976).

\section{Agency Cost}

Jensen and Meckling (1976) explained that the delegation of authority from the principal to the managers causes the agent does not always act in accordance with the principal's interests. This happens because managers tend to behave opportunistically to fulfill their interests, resulting in conflicts of interest. This condition results in agency costs. Agency costs are costs that must be incurred by the principal to reduce conflicts of interest. Components of agency costs incurred by the company are (1) audit fees as a form of costs incurred to oversee the actions of company management to act in the interests of shareholders, (2) bonding costs as a form of guarantee that company management does not take profits based on the facilities obtained, and (3) costs to restore the company's reputation if the company's management does not manage the company well, giving rise to lawsuits.

\section{Hypotheses Development}

Agency theory explains the delegation of authority from the principal as the owner of the company to the agents or managers as the party managing the company influencing the information asymmetry between the principal and the agent. This happens because 


\section{Herianti \& Marundha \\ Transfer Pricing, Agency Costs, and Financial Reporting Aggressiveness...}

the agent has the motivation to not act in accordance with the interests of the principal. This condition is caused by the opportunistic behavior of the managers to fulfill their interests (Shleifer \& Vishny, 1997), so the principle of effort tries to reduce the managers' opportunistic behavior through a monitoring mechanism. As a result of a conflict of interest, the principal is willing to bear agency costs (Jensen \& Meckling, 1976). Opportunistic behavior of managers is done through aggressive financial reporting actions. Frank et al. (2009) states that financial reporting aggressiveness is earnings management actions taken by company management within or beyond the limits of applicable accounting principles.

The aggressiveness of financial reporting causes a bias in financial reporting because the financial statements do not reflect the actual condition of the company. Roychowdhury (2006) explained that the important reason managers do financial reporting aggressiveness is to avoid small profits, beat analyst estimates, and maintain company performance. Research Ding, Zhang, and Zhang (2007) showed that company managers conducted financial reporting aggressiveness through accrual or non-operating profit management of related party transactions or related parties.

Aharony et al. (2010) explained that the purpose of the company is to use transactions with related parties to increase the company's profit during the initial public offering period. Sales transactions with related parties are mostly used by IPO companies and parent companies to enable companies to regulate profit figures in such a way that they can influence the market. In addition, Hwang et al. (2013) stated that most transactions with related parties are arranged to meet management objectives. Beuselink and Deloof (2014) stated that members of business groups tend to be involved in the aggressiveness of financial reporting compared to non-business groups. Research conducted by Ying and Wang (2013) showed that most companies conduct aggressiveness in financial reporting followed by excessive tunneling by controlling shareholders to remove profits imported from IPO companies.

The results of the study of Rasheed et al. (2018) showed that transactions with related parties have a positive and significant effect on the aggressiveness of financial reporting. Consistent with Rasheed et al. (2018), the results of Marchini's research (2018), and Hwang et al. (2013) showed that transactions with related parties have a positive and significant effect on the aggressiveness of financial reporting. Based on the description, the hypothesis proposed in this study is as follows.

\section{$\boldsymbol{H}_{1} \quad$ : Transfer pricing has a positive effect on the aggressiveness of financial reporting.}

Jensen and Meckling (1976) explained that the delegation of authority from the principal to the agent causes the manager does not always act in accordance with the principal's interests. This happens because managers tend to behave opportunistically to fulfill their interests, resulting in conflicts of interest. As a result of conflicts of interest and asymmetry of information is the emergence of agency costs. Agency costs are costs that must be incurred by the principal to reduce conflicts of interest. Agency costs incurred 


\section{Herianti \& Marundha \\ Transfer Pricing, Agency Costs, and Financial Reporting Aggressiveness...}

by the company such as, (a) audit fees as a form of costs incurred to oversee the actions of company management to act in the interests of shareholders, (b) bonding costs as a form of guarantee that company management does not take profits based on the facilities obtained, and (c) costs to restore the company's reputation if the company's management does not manage the company well, giving rise to lawsuits.

Agency costs incurred by principals aim to suppress opportunistic managerial behavior in conducting financial reporting aggressiveness. Frank et al. (2009) stated that financial reporting aggressiveness is earnings management actions taken by managers within or outside the limits of applicable accounting principles. As a result, principals are willing to bear agency costs because the aggressiveness of financial reporting actions undertaken by managers can reduce the level of principal prosperity. Man et al. (2018) shows that agency costs negatively affect earnings management. Based on this description, this study proposes the following hypothesis.

$\boldsymbol{H}_{2}$ : Agency cost negatively affects the aggressiveness of financial reporting.

\section{Research Method}

This study uses financial statements of manufacturing companies listed on Indonesia Stock Exchange (IDX) through the website www.idx.co.id. The sampling technique uses purposive sampling through criteria, namely, (1) manufacturing companies listed on the Indonesia Stock Exchange during the 2013-2017 period, (2) publishing financial statements in rupiah, and (3) not having a negative profit (loss). Thus, this study obtained 61 companies, so there were 305 sample observations.

This study uses three variables consisting of independent, dependent, and control variables. The independent variables are transfer pricing and agency costs, the dependent variable is the aggressiveness of financial reporting, and the control variables are company size, sales growth, and return on assets. The following are measurements of these three types of variables.

\section{Transfer Pricing}

Santosa and Suzan (2017) explained that transfer pricing is the price contained in each product or service from one division that is transferred to another division within the same company or between companies that have a special relationship. Measurement of transfer pricing uses related party transactions (RPT) (Kiswanto \& Purwaningsih, 2014; Melmusi, 2016; and Nuradila \& Wibowo, 2018). The formula used to measure transfer pricing is as follows.

$$
\text { Related Party Transaction }=\frac{\text { Related Party Receivables }}{\text { Total Accounts Receivable }}
$$




\section{Agency Cost}

Agency costs are costs incurred by the principal to the agent to act in accordance with the interests of the principal. This study uses the ratio of sales to total assets (STA) (Man et al., 2018; and Chen, Hu, Wang, \& Tang, 2013) to measure agency costs. Man et al. (2018) explained that the low ratio of sales to total assets shows that the company's sales are bad because of poor managerial performance, so that agency costs get higher. In other words, the lower this ratio, the higher the agency costs. The formula used to measure agency costs is as follows.

$$
\text { Agency Cost }=\quad \frac{\text { Total Sales }}{\text { Total Asset }}
$$

\section{Financial Reporting Aggressiveness}

The aggressiveness of financial reporting is an act of earnings management carried out by managers within or outside the limits of applicable accounting principles (Frank et al., 2009). This study uses a modified Jones model to detect the aggressiveness of financial reporting (Dechow, Sloan, \& Sweeney, 1995). Following are the equations used to calculate the aggressiveness of financial reporting.

$$
\begin{aligned}
& \frac{T \text { Ait }}{\text { Assets } i, t-1}=k 1 t \frac{1}{\text { Assets } i, t-1}+k 2 \frac{\Delta R E V \text { it }}{\text { Assets } i, t-1}+k 3 \frac{P P E}{\text { Assets } i, t-1}+\varepsilon \\
& \text { NAit }=k 1 t \frac{1}{\text { Assets } i, t-1}+k 2 \frac{(\Delta R E V \text { it }-\triangle R E C \text { it })}{\text { Assets } i, t-1}+k 3 \frac{P P E}{\text { Assets } i, t-1} \\
& \text { DAit }=\frac{\tau \text { Ait }}{\text { Assets } i, t-1}-N \text { Ait }
\end{aligned}
$$

The control variable uses company size, sales growth, and return on assets. The size of the company is obtained from the natural logarithm of total assets, sales growth is obtained from (sales-sales-1) / sales-1. Furthermore, return on assets is obtained from (profit / total assets).

This study uses a panel data approach to estimate research hypotheses. Panel data is a combination of cross section data and time series (Winarno, 2015). Before making a regression estimate, this study will test the assumption of heteroscedasticity. Ghozali and Ratmono (2017) and Ekananda (2015) explain that white's cross-section heteroscedasticity can be used to correct parameter values obtained through OLS, so that it can be used as output in hypothesis testing. Furthermore, this study uses three panel data estimation methods namely, the common effect test, fixed effect, and random effect test to test the research hypothesis. In addition, this study also uses a paired test approach to determine the panel data estimation method that is suitable for testing the research hypotheses namely, the chow test, the multiplier lagrange test, and the hausman test. 


\section{Results and Discussion}

This study uses descriptive statistics to briefly describe the research variables. The following are descriptive statistics of research variables.

Table 1 Descriptive Statistic

\begin{tabular}{lccc}
\hline \multicolumn{1}{c}{ Variables } & Mean & Std. Deviation & Observations \\
\hline Transfer Pricing & 0.200497 & 0.295639 & 305 \\
Agency Cost & 1.187859 & 0.526286 & 305 \\
Size & 23.66719 & 5.204609 & 305 \\
Growth & 0.090655 & 0.179618 & 305 \\
Return on Asset & 0.097451 & 0.101206 & 305 \\
Financial Reporting Aggressiveness & 0.022261 & 0.077765 & 305 \\
\hline
\end{tabular}

Table 1 shows that the average transfer pricing value is 0.200497 . This value indicates that the average manufacturing company listed on the Indonesia Stock Exchange in the 2013-2017 period carried out transfer pricing of 20\%. Agency costs are 1.187859 indicating that the ratio of sales to assets of manufacturing companies during the 20132017 period is high (more than 100\%).

The size of the company is 23,66719 using natural logarithms, so it is known that the average assets of manufacturing companies during the 2013-2017 period is 23,66719 , sales growth is 0.090655 , showing an average growth of $9 \%$, and return on assets is 0.097451 indicating the average availability of total assets to generate a $9 \%$ profit. Furthermore, the aggressiveness of financial reporting is 0.022261 indicating the average aggressiveness of financial statements in manufacturing companies during the 2013-2017 period was $2 \%$. This value indicates that the aggressiveness of financial reporting is still relatively low. The standard deviation value indicates the fluctuation of research variable data with the number of observations for the six variables is 305 observations.

Table 2 shows that the correlation between independent variables is less than 0.80 . The results of this correlation prove that there is no multicollinearity in this research model.

Table 2 Independent Variables Correlation

\begin{tabular}{lrrrrr}
\hline & $\begin{array}{c}\text { Transfer } \\
\text { Pricing }\end{array}$ & \multicolumn{1}{c}{$\begin{array}{c}\text { Agency } \\
\text { Cost }\end{array}$} & Size & Growth & $\begin{array}{c}\text { Return } \\
\text { on Asset }\end{array}$ \\
\hline Transfer Pricing & 1.000000 & & & & \\
Agency Cost & -0.015094 & 1.000000 & & & \\
Size & 0.107709 & -0.026839 & 1.000000 & & \\
Growth & 0.079287 & 0.255469 & 0.081401 & 1.000000 & \\
Return on Asset & -0.057347 & 0.471944 & - & 0.106919 & 1.000000 \\
& & & 0.346711 & & \\
\hline
\end{tabular}

Based on Table 3, it is concluded that a suitable method for estimating the effect of transfer pricing and agency costs on financial reporting aggressiveness is the fixed effect method (Sig. Cross-Section F, $0.0046<0.05$ ). 
Tabel 3 Chow Test

\begin{tabular}{lrrr}
\hline Effects Test & Statistic & d. f. & Prob. \\
\hline Cross-section F & 1.649491 & $(60.239)$ & 0.0046 \\
Cross-section Chi-square & 105.680031 & 60 & 0.0003 \\
\hline
\end{tabular}

Based on Table 4, it is concluded that a suitable method for estimating the effect of transfer pricing and agency costs on the aggressiveness of financial reporting is the random effect method (Sig. Breush-Pagan ie, $0.0000<0.05$ ).

Table 4 Lagrange Multiplier Test

\begin{tabular}{lrrr} 
& \multicolumn{3}{c}{ Test Hypothesis } \\
Breusch-Pagan & Cross-section & Time & \multicolumn{1}{c}{ Both } \\
& 1.346556 & 110.7699 & 112.1165 \\
& $(0.2459)$ & $(0.0000)$ & $(0.0000)$ \\
\hline
\end{tabular}

Based on Table 5, it is concluded that the suitable method for estimating the effect of transfer pricing and agency costs on the aggressiveness of financial reporting is the fixed effect method (Sig. Cross-section ie, $0.0003<0.05$ ).

Table 5 Hausman Test

\begin{tabular}{lccc}
\hline Test Summary & Chi-Sq. Statistic & Chi-Sq. d. f. & Prob. \\
\hline Cross-section random & 22.976114 & 5 & 0.0003 \\
\hline
\end{tabular}

Based on Table 6 of the paired test summary results, it is concluded that a suitable method for estimating the effect of transfer pricing and agency costs on the aggressiveness of financial reporting is the fixed effect method.

Table 6 Summary of Panel Data Test Results

\begin{tabular}{|c|c|c|c|}
\hline No. & Metode & Pengujian & Hasil \\
\hline 1. & Chow Test & $\begin{array}{l}\text { Common Effect vs Fixed Effect (If Prob. > } 0.05 \text {, so } \\
\text { the suitable method to apply is Common Effect and } \\
\text { vice versa). }\end{array}$ & Fixed Effect \\
\hline 2. & $\begin{array}{l}\text { Lagrange } \\
\text { Multiplier } \\
\text { Test }\end{array}$ & $\begin{array}{l}\text { Common Effect vs Random Effect (If Prob. }>0.05 \text {, so } \\
\text { the suitable method to apply is Common Effect and } \\
\text { vice versa). }\end{array}$ & $\begin{array}{c}\text { Random } \\
\text { Effect }\end{array}$ \\
\hline 3. & $\begin{array}{l}\text { Hausman } \\
\text { Test }\end{array}$ & $\begin{array}{l}\text { Fixed Effect vs Random Effect (If Prob. }>0.05 \text {, so the } \\
\text { suitable method to apply is Random Effect and vice } \\
\text { versa). }\end{array}$ & Fixed Effect \\
\hline
\end{tabular}

Table 7 shows the estimated results of the effect of transfer pricing and agency costs on the aggressiveness of financial reporting. The results showed that the effect of transfer pricing on the aggressiveness of financial reporting has a coefficient value of -0.004167 , t-statistic is 0.039865 , and the probability is 0.9168 . This finding proves that transfer pricing has no significant effect on the aggressiveness of financial reporting. The existence of Minister of Finance Regulation (PMK) No.213 / PMK.03 / 2016 regarding 
additional documents and / or information that must be kept by taxpayers who conduct transactions with related parties which constitutes an improvement to the Regulation of the Director General of Tax No.23 / PJ / 2013 which regulates transfer pricing requires the creation of additional transfer pricing documents for transactions with related parties. The aim is to increase transparency regarding transfer pricing schemes. This condition causes management difficulties in managing earnings figures, so that transfer pricing cannot influence management to behave opportunistically in managing earnings.

Table 7 Estimation of the Effect of Transfer Pricing and Agency Costs on Financial Reporting Aggressiveness

\begin{tabular}{lrrr}
\multicolumn{1}{c}{$\begin{array}{c}\text { Independent Variables and } \\
\text { Control }\end{array}$} & Coefficient & t-Statistic & \multicolumn{1}{c}{ Prob. } \\
\hline Transfer Pricing & -0.004167 & -0.039865 & 0.9168 \\
Agency Costs & -0.049055 & -4.210845 & 0.0000 \\
Size & -0.011340 & -2.012239 & 0.0453 \\
Growth & 0.045502 & 2.181788 & 0.0301 \\
Return On Asset & 0.515738 & 6.880017 & 0.0000 \\
Constant & 0.295361 & 2.018044 & 0.0447 \\
F-Statistic & & 3.543303 & \\
Prob (F-Statistic) & & 0.000000 & \\
$R^{2}$ & & 0.490747 & \\
Adjusted R & & 0.352247 & \\
\hline
\end{tabular}

Note: This model free of heteroscedasticity problems with white cross-section standard errors and covariance (d.f corrected)

The results showed that the effect of agency costs on the aggressiveness of financial reporting had a coefficient value of -0.049055 , $t$-statistic was -4.210845 , and probability was 0.0000 . This finding proves that agency costs have a negative and significant effect on the aggressiveness of financial reporting. Agency costs are costs incurred by the principal to the agent to act in accordance with the interests of the principal. The aim is to reduce conflicts of interest between principals and agents. Agency costs incurred by the company, namely, (1) audit fees to control opportunistic managerial actions, (2) bonding costs to ensure that agents will not make decisions that are detrimental to the principal, and (3) residual loss as a result of manager decisions that should be able to optimize shareholder profits. This condition affects managers to reduce opportunistic behavior in managing company profits.

Average data shows that agency costs measured through comparison of sales with assets prove this ratio is high (more than 100\%), the aggressiveness of financial reporting measured through discretionary accruals has a low average value of $2 \%$. This data proves that when sales are high, agency costs are low. Low agency costs with low discretionary accruals prove that agency costs can directly mitigate the aggressiveness of financial reporting. This condition occurs because company managers tend to start switching to real earnings management compared to accrual earnings management that is easily detected by auditors (Roychowdhury, 2006). Return on assets and growth shows a positive and significant effect on the aggressiveness of financial reporting proving that managers use these two ratios as opportunities to conduct financial 


\author{
Herianti \& Marundha \\ Transfer Pricing, Agency Costs, and Financial Reporting Aggressiveness...
}

reporting aggressiveness. That is, the higher this ratio gives the potential for managers to behave opportunistically in conducting financial reporting aggressiveness.

\title{
Conclusion
}

The purpose of this study is to estimate the effect of transfer pricing and agency costs on the aggressiveness of financial reporting. The research sample uses manufacturing companies listed on the Indonesia Stock Exchange (IDX) for the period of 2013-2017. The results showed that transfer pricing had no significant effect on the aggressiveness of financial reporting. Meanwhile, agency costs have a negative and significant effect on the aggressiveness of financial reporting. The contribution of this research is through the Minister of Finance Regulation (PMK) No.213 / PMK.03 / 2016 regarding additional documents and / or information that must be kept by taxpayers who carry out transactions with related parties which is a refinement of Tax Director General Regulation No. 23 / PJ / 2013 can reduce the behavior of managers in managing earnings through transfer pricing schemes. Furthermore, conflicts of interest between principals and managers cause principals to incur agency costs to control opportunistic managers' actions. As a result, the prosperity of shareholders is reduced because of the company's financial burden.

This study has several limitations, namely (1) the research sample uses manufacturing companies listed on the Indonesia Stock Exchange (IDX) for the period 2013-2017, so it cannot be generalized to companies outside the sample, and (2) measurement of transfer pricing using only related party transactions (RPT). Meanwhile, the measurement of financial reporting aggressiveness only uses the modified Jones model. Therefore, further research is expected to (1) use companies other than manufacturing such as mining to see the consistency of research results, and (2) measurement of transfer pricing and financial reporting aggressiveness using proxies other than related party transactions and modified Jones models.

\section{References}

Aharony, J., Wang, J., \& Yuan, H. (2010). Tunneling as an Incentive for Earnings Management During the IPO Process in China. Journal of Accounting and Public Policy, 29(1), 1-26. https://doi.org/10.1016/j.jaccpubpol.2009.10.003

Ali, U., \& Hirshleifer, D. (2017). Opportunism as a firm and managerial trait: Predicting insider trading profits and misconduct. Journal of Financial Economics, 126(3), 490-515. https://doi.org/10.1016/j.ifineco.2017.09.002

Beuselinck, C., \& Deloof, M. (2014). Earnings Management in Business Groups: Tax Incentives or Expropriation Concealment. The International Journal of Accounting, 49(1), 27-52. https://doi.org/10.1016/j.intacc.2014.01.008

Chen, X. Hu, N., Wang, X., \& Tang, X. (2014). Tax Avoidance and Firm Value: Evidence from China. Nankai Business Rebiew International, 5(1), 25-42. https://doi.org/10.1108/nbri-10-2013-0037 


\section{Herianti \& Marundha \\ Transfer Pricing, Agency Costs, and Financial Reporting Aggressiveness...}

Dechow, P. M., Sloan, R. G., \& Sweeney, A. P. (1995). Detecting Earnings Management. The Accounting Review, 70,193-225.

Ding. Y., Zhang, H., \& Zhang, J. (2007). Private vs State Ownership and Earnings Management: Evidence from Chinese Listed Companies. Corporate Governance: An International Review, 15(2), 223-238. https://doi.org/10.1111/i.1467-8683.2007.00556.x

Ekananda, M. (2015). Ekonometrika Dasar Untuk Penelitian di Bidang Ekonomi, Sosial dan Bisnis. Jakarta: Mitra Wacana Media.

Frank, M. M., Lynch, L. J., \& Rego, S. O. (2009). Tax Reporting Aggressiveness and Its Relation to Aggressive Financial Reporting. The Accounting Review, 84(1), 467-496. https://doi.org/10.2308/accr.2009.84.2.467

Ghozali, I., \& Ratmono, D. (2017). Analisis Multivariat dan Ekonometrika: Teori, Konsep, dan Aplikasi dengan Eviens 10. Semarang: UNDIP.

Hwang, N. C. R., Chiou, J. R., \& Wang, Y. C. (2013). Effect of Disclosure Regulation on Earnings Management Through Related Party Transactions: Evidence from Taiwanese Firms Operating in China. Journal of Accounting and Public Policy, 32(4), 292313. https://doi.org/10.1016/j.jaccpubpol.2013.04.003

Jensen, M. C., \& Meckling, W. H. (1976). Theory of the Firm: Managerial Behavior, Agency Costs and Ownership Structure. Journal of Financial Economics, 3(4), 305-360. https://doi.org/10.1016/0304-405x(76)90026-x

Khanna, T., \& Palepu, K. (1997). Why Focused Strategies Maybe Wrong for Emerging Markets. Harvard Business Review. Reprint No. 9704.

Lee, M. G., P, W. J., \& Seo, Y. M. (2013). The Relationship Between Related Party Transactions and Management Forecasts. Korea International Accounting Association, 49, 49-80. https://doi.org/10.21073/kiar.2013..49.003

Man, Y., Locke, S., \& Wellalage, N. H. (2018). Earnings Management and Agency Cost: Evidence from China. Working Paper.

Rasheed, P. C., Abdul, P. C., \& Mallikarjunappa, T. (2018). Related Party Transactions and Earnings Management: An Empirical Examination of Selected Companies in India. IUP Journal of Accounting Research and Audit Practices, 17, 22-35.

Roychowdhury, S. (2006). Earnings Management Through Real Activities Manipulation. Journal of Accounting and Economics, 42(3), 335-370. https://doi.org/10.1016/i.jacceco.2006.01.002

Santosa, S. J. D., \& Suzan, L. (2017). Pengaruh Pajak, Tunneling Incentives dan Mekanisme Bonus terhadap Keputusan Transfer Pricing. Kajian Akuntansi. E-ISSN: 2581-074X, 76-83.

Schipper, K. (1989). Comentary Katherine on Earnings Management. Accounting Horizon.

Shin, H., \& Park, Y. S. (1999). Financing Constraints and Internal Capital Markets: Evidence from Korean Chaebols. Journal of Corporate Finance, 5(2), 169-194. https://doi.org/10.1016/s0929-1199(99)00002-4

Shleifer, A., \& Vishny, R. W. (1997). A Survey of Corporate Governance. The Journal of Finance, 52(2), 737-783. https://doi.org/10.1111/j.1540-6261.1997.tb04820.x

Sofyani, H., \& Rahma, N. (2017). Kenapa Seseorang Melakukan Manipulasi Laporan Keuangan? Studi Dengan Pendekatan Skenario Kasus Dilema Etika. Jurnal Akuntansi dan Keuangan Islam, 5(1), 31-46. https://doi.org/10.35836/jakis.v5i1.12

Suandy, E. (2006). Perpajakan. Edisi Kedua. Jakarta: Salemba Empat.

Ujiyantho, \& Pramuka. (2007). Mekanisme Corporate Governance, Manajemen Laba dan Kinerja Keuangan. Simposium Nasional Akuntansi X. Unhas Makasar.

Vajriyanti, E., Widanaputra, A. A G. P., Putri, I. G. A. M. (2015). Pengaruh Manajemen Laba Riil pada Nilai Perusahaan dengan Good Corporate Governance sebagai Variabel Pemoderasi. Simposium Nasional Akuntansi XVIII. USU Medan. 
Watts, L. R., \& Zimmerman, L. J. (1989). Positive Accounting Theory: A Ten Years Perspective. The Accounting Review, 65, 131-156.

Williamson, O. (1975). Market and Hierachies: Analysis and Antitrust Implications. New York: Free Press.

Winarno, W. W. (2015). Analisis Ekonomika dan Statiska dengan Eviews. Edisi 4. UPP STIM YKPN.

Yin, Q., \& Wang, L. (2013). Propping by Controlling Shareholders, Wealth Transfer and Firm Performance: Evidence from Chinese Listed Companies. China Journal of Accounting Research, 6(2), 133-147. https://doi.org/10.1016/j.cjar.2013.02.001 